\title{
Analysis of the Risk in Information Technology (IT) outsourcing In Public Organisations
}

\author{
Momoh A. Attai, Makoji Stephen \& Alfa Patrick Innocent \\ Federal Polytechnic, Idah - Kogi State. \\ odogbas@yahoo.com, maytovia@yahoo.com,alfaintellectual@yahoo.com
}

\begin{abstract}
Acquisition of Information Technology infrastructure is critical to the realization of good service delivery in public organizations, yet the ability to muster enough resources to mount viable IT infrastructure is lacking. The next viable option for public organizations is to outsource IT. However, IT outsourcing is not without its risk. The study through extensive literature review assesses the risk associated with IT outsourcing in public organizations. The paper concludes that that if due diligence is demonstrated in the pursuit of IT outsourcing by public organizations, the benefits of IT outsourcing could outweigh the risk involved.
\end{abstract}

\subsection{Introduction}

Globalization, astonishing adjustments of the latest technology, changes in the global economic clime, increasing global competition and power of customers, are impacting on the way and manner public organizations carry out their functions. One area that has received considerable attention in the past few decades is IT outsourcing. According to Diromualdo and Gurbaxani (1998), organizations consider the adoption of IT outsourcing as a veritable way of sustaining their competitive advantage and maintaining a sustained scale of growth. Similarly, Hirsheim (1997) maintained that organizations consider IT outsourcing as a cost saving measure and an important option that will enable organizations focus on their core business. Additionally, (Apte et al. 1997; Matthews, 2004) opined that the increasing need for cost-reduction has made IT outsourcing an important option for administrators in public Organizations.

Apte et al. (1997) who carried out a comparative research on IT outsourcing in countries like USA, Finland and Japan came up with results showing the types of IT functions that organizations commonly outsource, the extent to which such functions was outsourced and the views of administrators on the cost savings and comparative benefits and risk of IT outsourcing.

With Public Organizations' in Nigeria experiencing a nose dive in their statutory allocation, affording the huge capital needed for IT infrastructure has become a near impossible feat. IT outsourcing is become increasingly accepted as a means of lowering cost and maintaining a strategic focus on their core business. This view is amplified by Hitt, etal (2005), who opined that very few organizations can afford the cost of developing internally their information Technology (IT) and therefore outsourcing this important activities to vendors of course become the next strategic option. Similarly, Drucker, (1995) maintained that organizations outsource IT because it reduces cost, especially cost of labor associated with employee benefits and other ancillary cost of training and capital cost. Hitt et al (2005), notes that information technology (IT) as well as Research and Development (R\&D) are the commonly outsourced organizational functions but notes that IT outsourcing is the fastest growing industry. Aggarwal, (2005) notes that IT outsourcing is increasingly been embraced by public organizations. 


\section{IT outsourcing defined}

Rose Perot was the first person who made the use of IT outsourcing popular, when he established Electronic Data (EDS) IN 1962. They started their marketing campaign by saying to potential customer "you are good at designing and manufacturing widgets, but we are skilled with managing information technology. We will sell you the IT service that you require, and you can pay us periodically with a minimum commitment of two years" From that time until now, IT has been embraced by both private and public organizations. Willcocks et al. (1995), define IT outsourcing as a dispensing tool over the management of some or all of an organization's information technology, information systems, and related services to a third party. Costs and strategy may drive commercial organization to outsource IT functions to make money but public sector for social reasons rather than economic reasons. Elmuti and Kathawala (2000) consider IT outsourcing as a management strategy by which an organization entrusts main, non-core tasks to specific and competent service providers. Grover et al. (1994), defines "outsourcing of IS activities as the practice of contracting part or all of an organization's IS activities to an external provider".

Sprague and McNurlin (1993) referred to IT outsourcing as a process by which an organization turns over its computer operations or other information functions to a vendor for an agreed period of time. The duo maintained that IT outsourcing involves among other things, application outsourcing, infrastructure outsourcing, internet service providers, software maintenance and support as well as consulting services. Kweku-Muata and Ojelakin (2006) agreeing with Sprague and McNurlin (1993) on the different types of outsourcing available maintained that care and diligence must be taken when deciding on the outsourcing option to be adopted by organizations. They emphasized the need for the organization to be strategic about IT outsourcing as whatever decision is taken on IT outsourcing activity could either make or mar the organization. Goolsby, (2002) asserts that the management of IT outsourcing would require adequate skilled personnel who will provide the required strategic leadership. He went further in line with Muata and Ojelakin, (2006) submission that IT outsourcing is complex and strategic and that executives must exercise due diligence in weighing the risk and benefits of IT outsourcing in their organization before deciding on whether to outsource or not.

\section{Outsourcing Life Cycle}

The process of outsourcing is a systematic process which comprises of six stages; (Finlay and King, 1999).

Strategy: In the beginning top management evaluate the idea of outsourcing and identify the core competent area. It enables them to decide whether outsourcing could be done i.e. partially or completely in order to improve the quality of goods and reduce cost.

Selection: when an organization makes a decision to outsourcing, next stage is the selection of suitable vendor. The "best-fit" vendor selection depends on terms of price and competence in the area. 
Negotiation: This phase includes negotiating of agreement details with short-listed vendor(s) and signing the final contract. The outsourcing work scope and timelines is defined at this stage.

Implementation: After signing the contract with vendor, the next set of activities involves planning of knowledge, transition and handover of work to vendor, engaging them in operational activities, preparing a detailed schedule and budget in order to kick-off the task.

Management: this stage involves managing, the ongoing project from both ends i.e. client and vendor. Monitored factors are scope, schedule, risk, quality, customer satisfaction etc.

Completion: This is the final phase, it involves the completion of all the activities and formally closing them in mutual agreement with client and vendor.

\section{Risk of IT Outsourcing}

Risks are defined as uncertainties and un-desirable events that can inflict severe consequences on any business. They are normally associated with danger and perceived to be linked with negative outcomes. In IT outsourcing, various kinds of financial and legal risks have been identified which ranges from the issues of managerial control \& accountability to losing competitive advantage. These risks though not exhaustive are discussed below:

\section{Transaction or Hidden Costs}

Organizations' normally fail to assess the hidden costs which involve extensive amount of time, human resources and money when they are commencing contract with the vendor. Gonzalez, et al. (2005), described hidden cost involved like searching of appropriate vendor, site visits by consultant and employees including higher coordination costs because of pre-evaluation of infrastructure, legislation, skills and labor etc. similarly, staff layoffs from the organization and the control involve hidden costs (khan et al.2003). Tafti (2005) affirmed that hidden cost may include the costs of transmitting knowledge (know-how from the vender to the customer) involving the cost of subsequent data transfer, extra expenses in the form of an additional bandwidth or security measures reinforcement. These cost he submits makes the whole process particularly cumbersome if organizations do not actually weigh the cost and benefits of IT outsourcing before engaging a vendor.

\section{Myth of Cost Saving}

In IT outsourcing, cost benefit analysis is not easy as all relevant factors cannot be translated into monetary values. Most of the literature has identified cost saving as reason for IT outsourcing, (Kermic, et al.2006). However a survey conducted by Dom Berger and Fernandez (1999) shows that cost increased by $90 \%$ due to IT outsourcing. It may cause additional social and indirect costs such as contract generation, transition, as well as procurement costs. These writers maintained that IT outsourcing by organizations should be embarked upon the conviction that outsourcing is the most viable strategic option. 


\section{Deficient Quality}

Gonzalez, et al (2006), stated that the most significant risk is the potential lack of quality of IT infrastructure deployed during the course of outsourcing. This problem becomes particularly glaring when IT providers lack the requisite human resources to run the already outsourced function. In addition, lack of managerial knowledge may incite deficient quality and cause severe problems.

\section{Privacy and Security}

The service providers may lack several legal responsibilities such as corporate policy on individual privacy, data security, proper audit and control mechanism. Vijayan (2004) detects three major problems associated with the protection of individual privacy and data security in outsourcing which are: no laws and regulations, inefficiency in the enforcement of laws because of corruption and incompetence, and diversity and inconsistency with the foreign laws.

These efforts were noticed when computer center was set up primarily to provide rudimentary computer training to polytechnic community, followed by the setting up of another unit called MIS which is empowered only to produce plastic identity card to staff and students.

\section{Benefit of IT outsourcing}

Erber and Ahmed (2005), argue that cost reduction is a powerful driver in IT globalization and more than $40 \%$ expected cost saving have compelled organization to outsource the IT functions. Embleton and wright (1998) who carried out an elaborate study on the benefits of IT outsourcing came up with a compendium of benefits ranging from time saving, discovery of hidden costs, IT outsourcing serving as an avenue for organization to identify their core business areas, provision of access to talent, introduction of flexibility in management and accountability of commercial suppliers among others. Chopra and Meindl (2007) agreed with Embleton and wright (1998) however maintained that certain risks must be evaluated before outsourcing any functions. The duo maintained that organizations who fail to evaluate the risk and benefits of IT outsourcing stand to lose control if it out sources any broken process to the third part. They cautioned that IT outsourcing should only be seen as a strategic option after weighing the pros and cons of the whole process.

\section{Conclusion}

This paper has been able to the risk and benefits of IT outsourcing with particular reference to public organizations. The authors submit that if due diligence is demonstrated in the pursuit of IT outsourcing by public organizations, the benefits of IT outsourcing could outweigh the risk involved. 


\section{References}

Aggarwal, B.A (2005), “Transaction Cost Approach to Outsourcing Behavior: some Empirical Evidence”, Information \& Management, Vol. 30 No. 2, PP. 51-64.

Apte, D., Kern, T. And Mattison, D. (2002). "Culture, Power and Politics in ICT Outsourcing in Higher Education Institutions". European Journal of Information Systems, Vo1.11, No.2,pp. 159-173.

Chopra, S. and Meindi, p. (2007). "Supply Chain Management Strategy, Planning and Operation", $3^{\text {rd }}$ Edition. New Jersey: Prentice Hall

DiRomualdo, A. and Gurbaxaini, V. (1998), "Strategic intent for IT outsourcing”, Sloan Management Review, Vol. 39 No. 4, summer, pp. 67-80.

Domberger, S. and Fernandez, P. (1999), "Public-Private partnership for service industry”, Business Strategy Review, Vol. 10, No. 4, pp.29-39

Embleton, P.R. and Wirgth, P.C. (1998), "A practical guide to successful outsourcing", Empowerment in Organizations, Vol 6, No.3, pp.94-106.

Erber, G. and Sayed-Ahmed, A. (2005), "outsourcing. A global shift in the present", IT Industry, Intereconomices, Vol. 40 No.2, pp.100-12.

Gonzalez, R. Gasco, J. and Llopis, J. (2005), "Information systems outsourcing risks: a study of large firms", Industrial Management and Data Systems, Vol. 105, No. 1, pp. 4562.

Grover, V, Chen MJ and Teng TC (1994) "a descriptive study on the outsourcing of information system function”. Information \& Management 27, 33-44.

Hitt, L. M and Brynjolfsson, E. (1996) "Productivity, Business Profitability, and Consumer Surplus: Three different Measure information Technology value”, MIS Quarterly June

Khan, N., Currie, W., Weerakkody, V. and Desai, B. (2003), "Evaluating offshore IT outsourcing in India: supplier and customer scenarios", Proceedings of the $36^{\text {th }}$ Hawaii International Conference on Systems Sciences (HICSS'03).

Tafti, M.H.A. (2005), “Risks factors associated with offshore IT outsourcing”, Industrial Management and Data Systems, Vol.105, No. 5,pp. 549-560

Vijayan, J. (2004), “Offshore outsourcing poses privacy perils”, Computer World, Vol. 38 No. 8, p, 10.

Willcocks, L, Fitzgerald, G.and Feeny, D.(1995). Outsourcing IT: The Strategic Implications. Long range Planning, Vol. 28, No. 5, pp. 59-70. 